\title{
Efficient Pancreatic Islet Cell Preparation Utilizing a New Tissue Chopper Prior to Transplantation
}

Dear Sir,

In recent years, several techniques for recovering islets of Langerhans from the pancreas have been developed and tested in rodents, canine, and human models. While some investigators seek to isolate islets from surrounding exocrine tissue by hand picking $[1,2]$ or by density gradient separation [3], experiments in our laboratory and others [4-6] appear to indicate that this is not necessary for restoration of normal blood sugar after transplantation. Normoglycaemia in totally pancreatectomized dogs has been achieved after autotransplantation and allotransplantation of pancreatic tissue, previously dispersed by mincing and collagenase digestion alone. The methods developed in our laboratory are highlighted by the ease of preparation, which has been aided by utilization of an economical and practical food processor (Cuisinart, DLC.7) rather than an elaborate and expensive tissue chopper to mince the pancreas tissue.

Our technique of islet cell preparation in dogs or humans for splenic allotransplantation consists of the following steps: The pancreas is first removed and flushed with heparinized Ringer's lactate at $4^{\circ} \mathrm{C}$ in an iced saline bath. The organ is then immediately transferred to the sterile bowl of the food processor. Approximately $3 \mathrm{ml}$ of Hank's balanced salt solution (HBSS, Gibco) per $\mathrm{g}$ of tissue is added before mincing for 60 to $70 \mathrm{~s}$. All washes and the mincing are conducted at $4{ }^{\circ} \mathrm{C}$ to prevent warm ischemia. The pancreas fragments are then washed twice at $4^{\circ} \mathrm{C}$ in a refrigerated centrifuge (IEC, Clini-cool) at $2600 \mathrm{rpm}$ for one min. After washing, a sterile container with 2-3 ml HBSS per $\mathrm{g}$ of tissue and the fragments are placed in a waterbath. When the preparation reaches $37^{\circ} \mathrm{C}$, filter sterilized collagenase $(144 \mathrm{U} / \mathrm{g}$ of tissue for dog pancreases and $300 \mathrm{U} / \mathrm{g}$ of human pancreases) (Worthington, Type IV) is added. The pancreatic fragments are digested with collagenase for $3 \mathrm{~min}$ before addition of $4^{\circ} \mathrm{C}$ HBSS to halt the reaction. The mixture is then passed through a sterile $16 \times$ 16 mesh stainless steel screen to remove the fibrous and connective tissue. Four additional centrifugal washes with $\mathrm{HBSS}$ at $4{ }^{\circ} \mathrm{C}$ follow to remove the collagenase. After the final wash, the tissue is placed in a syringe for injection through an 18 gauge spinal needle into the splenic pulp. In more than thirty totally pancreatectomized dogs that received allotransplantation of islet cell fragments into the spleen, normoglycaemia was achieved within 24 to $72 \mathrm{~h}$.

Furthermore, we have used this new tissue chopper successfully in clinical autotransplantation of islet cell pancreatic fragments in cases of chronic pancreatitis. The technique is similar to that used for allotransplants with modifications in the amount of collagenase used and the length of digestion. Table 1 indicates these differences in the protocol used to treat the more fibrous pancreases obtained after $85-95 \%$ pancreatectomy.

The tissue chopper has thus proved to be a fast and efficient means of mincing human as well as normal canine pancreases. The

Table 1. Islet cell preparation protocols for human pancreases obtained from chronic pancreatitis specimens for autotransplantation

\begin{tabular}{|c|c|c|c|c|c|}
\hline $\begin{array}{l}\text { Pancreas weight } \\
\text { for processing } \\
\mathrm{g}\end{array}$ & $\begin{array}{l}\text { Mincing time } \\
\text { seconds }\end{array}$ & $\begin{array}{l}\text { Amount of HBSS } \\
\text { used in mincing } \\
\text { ml }\end{array}$ & $\begin{array}{l}\text { Collagenase } \\
\text { digestion }\end{array}$ & $\begin{array}{l}\text { Amount of islet cell } \\
\text { preparation for } \\
\text { infusion (volume } \mathrm{ml} \text { ) }\end{array}$ & $\begin{array}{l}\text { Transplantation } \\
\text { site }\end{array}$ \\
\hline 61.5 & $\begin{array}{l}75 \text { (removed } \\
\text { finely divided } \\
\text { pieces), then } \\
30 \text { (minced } \\
\text { remaining tissue) }\end{array}$ & 200 & $\begin{array}{l}90000 \mathrm{U} \text { for } \\
30 \mathrm{~min}\end{array}$ & 175 & Portal vein \\
\hline 33.2 & 90 & 100 & $\begin{array}{l}45000 \mathrm{U} \text { for } \\
30 \mathrm{~min} \text {. }\end{array}$ & 190 & Portal vein \\
\hline 54.0 & 85 & 150 & $\begin{array}{l}57600 \mathrm{U} \text { for } \\
20 \mathrm{~min} .\end{array}$ & 55 & Portal vein \\
\hline 27.0 & 90 & 125 & $\begin{array}{l}43200 \mathrm{U} \text { for } \\
30 \mathrm{~min} .\end{array}$ & 85 & Portal vein \\
\hline
\end{tabular}


successful use of this tissue processor in preparing pancreases is important because this device is far less expensive than the tissue chopper used by other investigators [6]. Our experimental and clinical data indicates that there are no compromises in the results obtained by its utilization.

Sincerely,

Debra A. Gordon,

Gerald H. MacKenzie, and

Luis $\mathrm{H}$. Toledo-Pereyra

\section{References}

1. Ballinger WF, Lacy PF (1972) Transplantation of intact pancreatic islets in rats. Surgery $72: 175-186$

2. Lacy PE, Kistianovsky M (1967) A method for the isolation of intact islets of Langerhans from the rat pancreas. Diabetes 16: 35

3. Lindail $A W$, Steffes MW, Sorenson R (1969) Immunoassayable insulin content of subcellular fractions of rat islets. Endocrinology 85: 218-223

4. Mirkovitch V, Campiche $M$ (1976) Successful intrasplenic autotransplantation of pancreatic tissue in totally pancreatectomized dogs. Transplantation 21: $265-269$

5. Kretschmer GJ; Sutherland DER, Matas AJ, Cain TL, Najarian IS (1977) Autotransplantation of pancreatic islets without separation of exocrine and endocrine tissue in totally pancreatectomized dogs. Surgery 82: 74-81

6. Matas AJ, Sutherland DER, Steffes MW, Najarian JS (1976) Short-term culture of adult pancreatic fragments for purification and transplantation of islets of Langerhans. Surgery 80 : 183-191

Luis H. Toledo-Pereyra, M. D., Ph. D.

Mount Carmel Mercy Hospital

Department of Surgery

Section of Transplantation and

Surgical Research

Detroit, MI 48235

USA

\section{Rapid Glycosylation of Haemoglobin}

Sir,

We would like to comment further on the very thorough work on rapid glycosylation of haemoglobin as determined by column chromatography reported by Dr. Svedsen and colleagues in the August issue of Diabetologia. Our studies on short term glycosylation in vitro and in vivo fully support those of Dr. Svedsen in demonstrating a rapid rise in levels as detected by Quik-sep column chromatography though not by the Fluckiger technique.

We would like to add some further details. Firstly, rapid glycosylation continues in vitro at $23^{\circ} \mathrm{C}$ (room temperature) in EDTA blood samples with a high glucose concentration; thus at a blood glucose concentration of $25 \mathrm{mmol} / 1$ the $\mathrm{HbA}_{1}$ level measured by column chromatography increased from $7-9 \%$ in $6 \mathrm{~h}$. Secondly, rapid glycosylation was reversed by incubation of red cells washed in saline at $23^{\circ} \mathrm{C}$ for $8-12 \mathrm{~h}$, and the $\% \mathrm{HbA}_{1}$ level then remained stable for the next $24 \mathrm{~h}$. This is simpler than $37^{\circ} \mathrm{C}$ incubation, and avoids another possible source of error. This is that at $37^{\circ} \mathrm{C}$, incubation of washed red cells for more than $12 \mathrm{~h}$ results in an unpredictable increase in $\% \mathrm{HbA}_{1}$ levels measured by column chromatography, which is associated with denaturation of haemo- globin shown by change in absorption spectrum and ultimately visible change in colout of the samples.

This means that it is unlikely to be safe to incubate all blood samples overnight at $37^{\circ} \mathrm{C}$ before measurement of glycosylated haemoglobin. In routine laboratories where overnight preparation of samples (approximately $16-18 \mathrm{~h}$ ) is more convenient than $7 \mathrm{~h}$ incubation, it might be best to keep thoroughly washed red cells al room temperature for $16-24$ h before assay. This requires a lowering of the normal range by approximately $1 \%$ glycosylatec haemoglobin.

Yours sincerely, R. Paisey, C. Pennock, Caroline Owens, M. Hartog, D. White

R. Paisey

Department of Medicine

Southmead Hospital

Southmead Road

Bristol BS $105 \mathrm{NB}$

England 